\title{
THE ADJUSTED NET ASSET, A PATRIMONIAL METHOD TO DETERMINE THE VALUE OF ECONOMIC ENTITY
}

\author{
Mihaela NICOARĂ \\ "Dimitrie Cantemir" Christian University Bucharest \\ mihaela.nicoara@cantemircluj.ro
}

\begin{abstract}
One of the goals of evaluation is applying the management based on value, in order to redirect the performances of different activities of the enterprise meaning when, how, and how much to extend the businesses that bring value, and which of the operational measures have the biggest potential to raise the value. The evaluation is based on balanced sheet, balance of accounts, and then the economic balance that includes both the patrimony of the economic entity in economic values and the turnover that the entity is able to achieve. The determination of the adjusted net asset is based on the achieved economic balance. The adjusted net asset is considered the most important patrimonial value because it takes into consideration the incident of various factors on the real value of the assets and on the liabilities or debts of the entity. The evaluation of the economic entity is essential in many moments of the existence of an enterprise, as acquisition, divesture, stock holdings, stock issued, issued shared, stock sales, absorptions, fusions, etc. The specialized literature mentions as essential patrimonial values: the active asset, the adjusted active asset, the active asset reduction. Taking into consideration only their own funds and equity as resource of financing the patrimonial assets of the economic entity, we can affirm that these values correspond to the seller' view that considers that the economic entity is terminating its activity and his main concern is only the possible selling prices.
\end{abstract}

Keywords: economic entity, value, active asset, adjusted net asset, economic balance sheet. JEL CODE: D

\section{Introduction}

There are certain moments in the existence of an economic entity which impose the

evaluation of the business, such as:

- patrimonial operations as acquisitions, fusions, capital increases;

- divestures, divestments;

- litigations;

- shareholders disagreements;

- financial institutions' solicitations, before deciding the financing of the enterprise;
- various legal actions with patrimonial purpose (succession, bankruptcy, mortgage);

The patrimonial approach to the evaluation of the economic entity has the purpose of the estimation of a market value of the enterprise patrimony, starting with the financial statements without taking into account the economic potential of the entity.

The evaluation methods that lead to the attainment of the patrimonial values of the business are sustained by the theory 
according to which the value of a business is provided by the sum of all their elements values: tangible and intangible fixed assets, securities, stocks, cash flows. Therefore, the evaluation methods imply the calculation of the market values or other current values, of the business assets and their sum with or without taking into account the business liabilities. We start from the idea that the business' patrimonial elements could be disposed or separately sold.

For calculating and determining patrimonial values, the balance sheet is usually reprocessed to eliminate the influence of some factors that could distort the existing economic value of the enterprise, such as: the financial and accounting principles that don't allow to reflect the present value of the patrimonial elements, some administrative measures concerning the evaluation of some assets or concerning fiscal aspects that require records not related to the particular situation of the enterprise etc.

\section{The Literature and the Practice in the Field}

The economic theory offers various concepts of the value. The value of a good or asset is based on the notion of exchange, the price being the balance point where the seller and the buyer accept the transaction.

To evaluate means to estimate, to form an opinion of the value, through specific steps made by a specialized enterprise or a professional agent.

The comprehensive character of an economical entity evaluation process depends on:

- the nature and the size of the economic entity

- the patrimony of the economic entity and the possibility of its valorization taking into account that the enterprise assets were acquired in different moments and with different prices which are evaluated as their utility value.

- the evaluation of the economic entity leads to the determination of some differences between the paper and factual reports.

The reevaluation means to evaluate once more, at one moment, meaning to establish the value at the current price or at the market price.

The value of the business reflects the result of a judgment based on an appreciation according to several criteria of comparison, analysis, calculations or surveys.

Regarding the business value, there are several directions [1]:

- The Fundist current (Adam Smith), according to which the value of a business is given by the fund of work invested in the enterprise assets and the final products stock for sale and with-profits funds.

- The Materialist or realist current which considers the capital as a main factor of the value, meaning that the market value of the enterprise is based on its assets including the invested capital.

- The Neofundist current that considers that at the core of the enterprise value are the future flows which are generated by the tangible and intangible fixed assets in their exploitation process.

\section{The Adjusted Net Asset, a Patrimonial Method of Determination of the Economic Entity Value}

The financial and accounting value of an economic entity is given by net accounting asset, net patrimony or net situation, based on the annual financial statements.

The net accounting asset is a value "less significant due to the limits that every accounting system has regarding the assurance of a consistency between the accounting value and the economic value of the enterprise assets" [2]. 
The net accounting asset is the excess of all the assets and entitlements of an economic entity over their liabilities:

NAA $=$ Total assets - Total liabilities

Where:

$\mathrm{NAA}=$ net accounting asset.

$$
\text { Or }
$$

$\mathrm{NAA}=$ Own capital + Net result after distribution or allocation

The net asset needs to be adjusted to ensure that the accounting of the enterprise reflects exactly the economic reality, by eliminating the factors that produce distortions between the balance sheets and the economic balance of the economic entity. In the analysis of the global efficiency of an enterprise is particularly important the quantity and the quality of the financial and accounting information existent at a given moment in the economic system of the enterprise [3].

The reevaluation of the fixed assets represents the economic operation, as a result of which the accounting value of the fixed assets is correlated with their existing value, assuring therefore the registration of relevant annual data, and through that a more accurate disclosure for the accounting information users.

During the reevaluation the comparison between the fair-valued assets and the accounting value is realized, from the date of the balance sheet of the concerned noncurrent asset:

- The fair value is the actual value, determined based upon certain evaluations usually carried out by professionals with qualification in evaluation, members of a professional organization or agency from the field.

- The fair value of the tangible fixed assets is usually determined starting from their market value.

- The accounting value of an asset represents the entrance value (or, where applicable, the gross accounting value fixed as a result of the last reevaluation) diminished or reduced by the dumping and the depreciation adjustments concerning that asset.

The accounting in historical costs is a method of applying the monetary nominalism principle, whereas the fair-valued accounting is a form of market accountings.

Also known as the "origin cost principle" [5], the principle of historical costs means to preserve, at the balance sheet positions, the entrance values which are historical values, adjusted with the registered amortizations and provisions. The historical costs principle is based on the stable monetary union hypothesis, meaning that is meeting the nominal values of the currency without taking into account the variations of the purchasing power.

The adjusted net asset or the corrected net accounting asset is considered the most important patrimonial value because is taking into account the impact of certain factors that lead to the reflection of the real value of the assets and the liabilities of the enterprises. It concerns the monetary devaluation, the currency exchange ratio, the evolution of the prices, the enterprise's assets utility, the economic depreciation and depreciation, the asset elements that don't have economic value.

The additive method implies the determination of the adjusted net accounting asset (ANAA), with the assumption of continuing activity, following the formula [6]:

ANAA $=$ ANA \pm Active corrections \pm Liabilities corrections

The specialty literature shows that some evaluators prefer instead of the additive method the subtractive method, as follows:

ANAA $=$ Adjusted (corrected) activesAdjusted (corrected) liabilities

The steps to follow for the determination of the adjusted net asset or the reevaluated net asset refer to: 
a) the corrections of the assets

b) the corrections of the liabilities

The corrections of the assets concern:

$a_{1}$ ) - the elimination of the assets excepting the exploitation

$a_{2}$ ) - the determination of the market values or of other current and existing values of the assets of exploitation or used in exploitation. The elimination of the assets apart from the exploitation is referring to the assets without utility or with reduced utility, assets owned as investments, extra assets.

The international standards of valuation (IVS) define the market value as "the estimated sum for which an asset or a liability could be changed at the valuation date, between a committed buyer and a committed seller, in an impartial transaction, under an appropriate marketing and where the stakeholders were acting knowingly and well-informed, cautiously and without constraint" [7].

1) if it were to determine ANAA at the level of an economic entity, through both methods, starting with the following data taken over its balance sheet:

- Incorporation costs

- Buildings

- Equipment

- Stocks

- Cash register

- The bank

- Capital stock (equity or share capital)

- Supplies

- Revenue

- Long term bank loans

(credits)

- Suppliers (providers, contractors)

- Creditors

- Fixed assets suppliers
15.000 lei;

200.000 lei;

250.000 lei;

300.000 lei;

10.000 lei;

150.000 lei;

100.000 lei;

10.000 lei;

55.000 lei;

200.000 lei;

400.000 lei;

80.000 lei;

80.000 lei;
We are assuming that we will not take into consideration the equity or value taxation or the taxation savings.

To solve the situation, we notice that we don't have elements to submit correction on asset. The incorporation costs, regarded as only a division of the costs or spending on several accounting periods from the point of view of the evaluator, are considered non values and are eliminated; thus they are deducted from the asset. We don't have other corrections to make in this case.

a) In the case where the additive method is applied: $\mathrm{ANAA}=\mathrm{ANA} \pm$ Asset corrections \pm Asset liabilities $=(100.000+10.000+55.000)$ $5.000=150.000$ lei;

b) In the case where the subtractive method is applied:

ANAA $=$ Adjusted assets - Liabilities corrections $=(10.000+150.000+15.000+$ $200.000+250.000+300.000)-(400.000+$ $80.000+200.000+80.000)-15.000=150.000$

2) If we assume that the firm $W$ established its patrimony as it turns out from the balance sheet at the end of the financial year 2018:

Tangible fixed assets

100 lei;

Financial fixed assets

2.400 lei;

Net worth

240 lei;

Equity (own capital)

2.240 lei;

Financial liabilities (debts)

500 lei;

Tangible fixed assets are formed from calculations used by the firm for own needs and which has a market value of 220 lei.

Financial fixed assets include stocks and shares of the companies listed on the stock exchange, whose value on the stock market represents 2.500 lei for the share owned by the company.

The Income taxes are 16\% and the Surtaxes are $10 \%$.

Determine ANA and ANAA. 
To determine the accounting asset, we are doing like this:

$\mathrm{ANA}=\mathrm{A}-\mathrm{D}=2.740-500=2.240$ lei; ANAA $=$ ANA \pm Asset corrections \pm Liabilities corrections

ANA $=+2.240$ lei;

- Gross Equity tax for tangible + 120 lei; fixed assets

$220-100=120$ lei

- Gross Surtax for tangible - 12 lei;

fixed assets

$120 * 10 \%=12$ lei

- Gross worth value on stocks + 100 lei;

$2.500-2.400=100$ lei

- Tax on worth value stocks - 10 lei;

$100 * 10=10$ lei

$\mathrm{ANCC}=$

2.438 lei;

\section{Conclusions}

The patrimonial values are used in practice for comparative analyses. In commercial transactions, the buyer is interested in using the patrimonial value, taking into account the static character of the result, while the seller is seeking to rely on dynamic values, using profitability and cost efficiency based on market values which are, usually, higher than the patrimonial values.

A patrimonial value is a sum of account receivable, debts and tangible assets, without taking into consideration the goodwill, which is seen like extra revenue and brings equity to the entity.

The evaluation standards SEV 5, "The evaluation of the enterprise", define the goodwill as being an intangible asset, which appears as a result of the reputation, prestige, customer base and other factors that cannot be measured or separate identified, but are contributing to obtain revenue.

The patrimonial values limits in practice:

- exclude from calculation the capital investment return, being a patrimonial method not an efficiency method;

- the lack from calculation of the goodwill;

- doesn't take into consideration the strategy of the economic entity;

- requires a significant period to make the calculation.

\section{References}

[1] Işfănescu, A., Robu, V., Anghel, I., \& Tuţu, A., Evaluarea întreprinderii, Editura Tribuna Economică, Bucureşti, p.20, 1999.

[2] Toma, M., Iniţiere în evaluarea întreprinderilor, Ediţia a IV-a, revizuitã și adãugitã, Editura CECCAR, București, p. 103, 2011.

[3] Crecană, C., Rentabilitatea întreprinderilor mici şi mijlocii, Editura Economică, Bucureşti, p. 29, 2000.

[4] Matiş, D., Pop, A., Contabilitatea financiară, Ediţia a III-a, Editura Casa Cãrţii de Ştiinţã, Cluj-Napoca, p. 150, 2010.

[5] http://store.ectap.ro/articole/69.pdf

[6]file://D:/FACULTATE/EVALUAREA\%20INTR\%202011/Suport\%20studiu\%20admitere\%20master \%20DE Filiera\%202 Material\%201 2018.pdf

[7] http://site2.anevar.ro/sites/default/files/page-files/6 sev 104 tipuri ale valorii.pdf 